\title{
Exogenous Procoagulant Factors as Therapeutic and Biotechnological Tools
}

Ana Marisa Chudzinski-Tavassi*, Linda Christian Carrijo Carvalho, Miryam Paola Alvarez-Flores and Sonia Aparecida de Andrade

Laboratory of Biochemistry and Biophysics, Butantan Institute, São Paulo, Brazil

\begin{abstract}
A diversity of animal venoms and secretions has been described to affect the hemostatic system with actions on blood coagulation and fibrinolytic pathways. These biological materials are rich sources of proteins and peptides with distinct biochemical properties, which have a biological function for the animal. Snake venoms are one of the richest sources of exogenous hemostatic factors, especially procoagulant proteins. Insects are another important source of proteins and peptides targeting the hemostatic system. Exogenous procoagulant factors have a large functional diversity and present potential applications in health and biotechnology. They have been important tools for the diagnosis and therapy of several blood coagulation disorders. Recently, many studies have pointed out that exogenous hemostatic factors can also display non-hemostatic functions, bringing new perspectives for the study of these molecules.
\end{abstract}

Keywords: Exogenous hemostatic factors; Coagulation; Fibrinolysis; Procoagulant; Anticoagulant; Toxins

\section{Introduction}

Many compounds affecting the hemostatic system have been described from several sources such as fungus, bacteria, plants, animal venoms, and animal fluids and secretions, playing roles on biological processes, such as feeding, digestion, self-defense, and also in the internal physiological process of the organism [1]. Especially the animal venoms and secretions are rich and complex mixtures of biologically active proteins and peptides that exhibit several functions on the hemostatic system.

Exogenous factors affecting hemostasis, especially toxins from animal venoms, have largely been studied with a purpose to understanding the pathophysiology of envenoming in human accidents involving snakes, spiders, caterpillars, and wasps, for instance [2]. Many of these toxins are proteins, triggering pro or anticoagulant activities, and they have been characterized in respect to their biochemical and pharmacological properties. They can be involved in various effects observed in the poisoning, such as bleeding, hemorrhage and disseminated intravascular coagulation [3].

On the other hand, efforts have been applied on the research of these proteins for cataloging and classifying them according to sequence analysis, structure and activity [4-6]. In this regard, new molecules have been discovered, opening new perspectives for basic and applied researches. These molecules can point out novel mechanisms of action, undiscovered molecular interactions and new classes of enzymes and inhibitors.

Exogenous hemostatic factors can also have a wide range of biotechnological and pharmacological applications [3]. Based on their specific activities, exogenous factors can be used as reagents in diagnostic kits to detect hemostatic disturbances and deficiencies of a clotting factor, or even be used as components for kits to monitor hemostatic parameters [7]. In addition, exogenous factors have been suggested as therapeutic agents for various disturbances that involve unbalanced hemostasis, such as thrombosis, arthrosclerosis, stroke, clotting factor deficiencies, cancer and bleeding reverser [8,9].

\section{The sources of exogenous hemostatic factors}

Important sources of exogenous hemostatic factors are animal venoms mainly from snakes, which involve specialized structures for venom production, storage and injection. Toxins present in these venoms intended to act on the hemostatic system of the prey. On the other hand, there are venom toxins that can be obtained from animal tissue extracts, such as the caterpillar bristles, because they do not have well specialized structures devoted to venom production and injection, which means they are disperse over the caterpillar's body [10]. In general, the exogenous action on hemostasis of these toxins has a defense purpose, protecting the poisoning animal against predators.

In the Insecta class there are a few members reported that produce toxins with direct activities on coagulation and fibrinolysis. Moth caterpillars from the genus Lonomia can cause a severe hemorrhagic syndrome after skin contact with their bristles, and they can be found mainly in Brazil and Venezuela [2]. In the South and Southeast regions of Brazil, the species Lonomia obliqua has been associated with human envenomation accidents since the 1980s, and it is considered as a public health problem [11]. The mechanism by which Lonomia obliqua induces the hemorrhagic syndrome is through a consumptive coagulopathy due to procoagulant toxins contained in its venom [12]. Wasps' venom has proteolytic enzymes that display anticoagulant function by hydrolyzing several clotting factors, such as FII, FVII, FVIII, FIX, FX and tissue factor (TF) [13].

White (2005) listed the snakes of medical importance that affect the hemostatic system. The venom of these reptiles can cause several types of coagulopathy including procoagulant and anticoagulant actions, fibrinogen clotting, fibrinolysis, platelet-activation, prothrombotic and hemorrhagic states [14]. A diversity of toxins from snake venoms has been described: hemorragins, clotting factor activators, clotting

*Corresponding author: Ana Marisa Chudzinski Tavassi, Laboratory of Biochemistry and Biophysics, Butantan Institute, Av. Vital Brasil, 1500, 05503900, São Paulo, SP, Brazil, Tel: 55112627 9738; Fax: 55113726 1024; E-mail: ana.chudzinski@butantan.gov.br

Received February 28, 2014; Accepted March 25, 2014; Published April 05, 2014

Citation: Chudzinski-Tavassi AM, Carrijo-Carvalho LC, Alvarez-Flores MP, Andrade SA (2014) Exogenous Procoagulant Factors as Therapeutic and Biotechnological Tools. J Blood Disorders Transf 5: 209. doi: 10.4172/21559864.1000209

Copyright: (C) 2014 Chudzinski-Tavassi, et al. This is an open-access article distributed under the terms of the Creative Commons Attribution License, which permits unrestricted use, distribution, and reproduction in any medium, provided the original author and source are credited. 
factor inhibitors, proteins affecting platelets and fibrinolysis [15]. Disturbances in the hemostatic system are not the main effects found for fish and spider venoms, except for the genus Loxoceles [16]. Envenomation by Loxoceles spiders causes an increase in the activated partial thromboplastin time and depletion of the clotting factors VIII, IX, XI, and XII, by a procoagulant activity causing disseminated intravascular coagulation [16]. However, some effects on hemostasis have been described for fish and other spider venoms $[17,18]$.

Apart from venoms, other animal fluids are the source of diverse proteins affecting hemostasis, such as hemolymph [19] and the bloodsucker's saliva, which have actions over the coagulation system of another animal for feeding. In this case, exogenous factors act on the hemostasis of another animal to enhance the time of access to blood fluid through the wound made by specialized structures of the bloodsuckers [20]. Therefore, these animals have been an important source of new anticoagulants, among them, clotting inhibitors, fibrin(ogen)olytics, plasminogen activators and platelet inhibitors [21].

\section{The targets on blood coagulation and fibrinolytic pathways}

According to the target and the kind of activity, exogenous factors can have pro or anticoagulant effects. Their target may virtually be any factor on the coagulation or fibrinolytic system. The coagulation system functions by intrinsic pathways, with the actions of distinct factors in a descending cascade that results in the activation of prothrombin (FII) into thrombin (FIIa), which finally converts fibrinogen into fibrin clots. Activation of the coagulation cascade can start with tissue factor and phospholipids, which form an enzymatic active complex with FVIIa, or with the formation of an enzymatic complex consisting of FXIIa, prekallikrein and high molecular weight kininogen (HMWK), which had been previously distinguished as extrinsic and intrinsic pathways, respectively. Physiologically, there are intricate and complex interactions between each clotting factor, with regulation points through feedback mechanisms, endogenous inhibitors and cofactors [22]. Following the most recent concept, on a cell-based model, the pathways are not redundant, but operate in parallel [23].

The majority of clotting and fibrinolytic factors is synthesized and circulates in the blood in zymogen form. Exogenous factors can act through proteolytic activity by activating clotting factor zymogens (e.g. prothrombin activators, FX activators) or acting like a clotting factor (e.g. thrombin-like toxins), usually displaying procoagulant activity. Conversely, procoagulant proteins have been indicated as anticoagulant agents, because these enzymes can be administrated in therapeutic doses to deplete clotting factors, especially fibrinogen, without the bleeding risk commonly associated to therapeutic anticoagulants [24]. The thrombin-like enzymes have been highlighted as interesting therapeutic molecules for diseases associated to ischemic conditions, such as myocardial infarction and stroke, and in the prevention of thrombus formation and reduction of blood viscosity [25]. Exogenous inhibitors usually display anticoagulant activity by specifically inhibiting the activity of a clotting factor. Proteolytic enzymes that act on the fibrinolytic system have also been described, e.g. plasminogen activators, which have anticoagulant activity [26], and fibrinolytic enzymes, which are in general antithrombotic, because they can act on cross-linked fibrin $[27,28]$.

\section{The distinct groups of exogenous hemostatic factors}

Exogenous hemostatic factors identified in animal venoms or in the saliva of hematophagous animals can exert their effects on the hemostatic system by several mechanisms affecting coagulation, fibrinolysis, platelet function and vascular integrity. Larréché et al. [29] classified them into four main groups: hemorrhagins; components affecting platelet function (which can also be referred as platelet activators/inhibitors); components affecting coagulation; and, components affecting fibrinolysis.

In general, the exogenous factors can be considered as two separated groups: procoagulants and anticoagulants. The procoagulants can include platelet activators, clotting factor activators, and thrombin-like enzymes, whereas the anticoagulants can include platelet inhibitors, fibrin(ogen)olytics, plasminogen activators, and clotting factor inhibitors, since they are able to prevent blood clotting and maintain blood incoagulable.

This paper is focused mainly on the exogenous procoagulant proteins from snakes and insects. The hemorrhage and components affecting platelet functions are out of the scope, but these groups of molecules were discussed by some authors [8]. For a review on the exogenous anticoagulants the reader is referred to Monteiro [30] and Kini [31,32].

Table 1 shows some proteins acting as procoagulants, which have been isolated from animal venoms or saliva of hematophagous animals and biochemically characterized

\section{Exogenous procoagulant factors}

In general, the exogenous procoagulant proteins are metalloproteinases or serine proteinase that display activity on a specific factor of the coagulation cascade. These proteins usually hydrolyze the zymogenic form of a clotting factor converting it in the active form. Snake venoms are the richest sources of procoagulant toxins among the animal venoms [15], but these enzymes can also be found in arthropod venoms $[4,33]$.

Prothrombin activators: FXa is the physiological activator of prothrombin. The hydrolysis of prothrombin in thrombin by FXa is enhanced up to 300,000 times in the presence of phospholipids, FVa and calcium ions, which form with FXa, the prothrombinase complex [34]. Meizothrombin is formed as an intermediate product, by consecutive cleavages at $\mathrm{Arg}^{323}-\mathrm{Ile}^{324}$ and $\mathrm{Arg}^{274}-\mathrm{Thr}^{275}$. The intermediate products generated in the hydrolysis of prothrombin by FXa in absence of prothrombinase complex are Fragment 1.2 and Prethrombin 2 by cleavage at $\mathrm{Arg}^{274}-\mathrm{Thr}^{275}$ followed by cleavage at $\mathrm{Arg}^{323}-\mathrm{Ile}^{324}$ [35]. The exogenous prothrombin activators can differ in the specific cleavage site on prothrombin, the end products formed (meizothrombin or $\alpha$-thrombin), the cofactor requirements (calcium ions, phospholipids and FVa) and the susceptibility to proteinase inhibitors. Based on these properties, the exogenous prothrombin activators, especially those from snake venoms, can be classify into four main groups [36]. Group $\mathrm{A}$ and $\mathrm{B}$ prothrombin activators are metalloproteinases that hydrolyze prothrombin into meizothrombin. Prothrombin activators from groups $\mathrm{C}$ and $\mathrm{D}$ are serine proteinase, which are able to generate active thrombin ( $\alpha$-thrombin) $[28,36]$. These toxins have a FX-like domain, and are found in Australian Elapid snake venoms. Also, they have been well distinguished by molecular phylogenetic analysis [37]. Group C prothrombin activators also show a FV-like domain and resemble the prothrombinase complex [38]. Both domains are highly conserved in the elapid family and present high similarity with mammalian FXa, e.g. Hopsarin D from Hoplocephalus stephensi, Trocarin D from Tropidechis carinatus [37] and FXa-FVa complex, e.g. Pseutarin C [39]. Kini [36] has reported examples and the biochemical properties of prothrombin activators from snake venoms belonging to the distinct 
Citation: Chudzinski-Tavassi AM, Carrijo-Carvalho LC, Alvarez-Flores MP, Andrade SA (2014) Exogenous Procoagulant Factors as Therapeutic and Biotechnological Tools. J Blood Disorders Transf 5: 209. doi: 10.4172/2155-9864.1000209

Page 3 of 10

\begin{tabular}{|c|c|c|c|c|c|c|}
\hline Molecule function $^{a}$ & Molecule name & Animal source $(s p)$ & $\begin{array}{l}\text { Molecular } \\
\text { mass (Da) }\end{array}$ & Additional targets & Functional characteristic & Reference $^{b}$ \\
\hline \multirow{4}{*}{ Factor $\mathrm{X}$ activators } & $R V V-X$ & $\begin{array}{c}\text { Vipera russelli } \\
\text { (Daboia russelli) }\end{array}$ & 92,880 & FIX & metalloproteinase, $\mathrm{Ca}^{2+}$ dependent & $\begin{array}{l}\text { Kisiel et al. [52]; } \\
\text { Takeya et al. [50] }\end{array}$ \\
\hline & VLFXA & Vipera lebetina & 89,400 & FIX & metalloproteinase, $\mathrm{Ca}^{2+}$ dependent & Siigur et al. [51,54] \\
\hline & - & Bungarus faciatus & 70,000 & $\begin{array}{c}\text { S-2266 and S-2302 } \\
\text { (kallikrein substrates) }\end{array}$ & serino proteinase, $\mathrm{Ca}^{2+}$ dependent & Zhang et al. [49] \\
\hline & Losac & Lonomia obliqua & 45,000 & 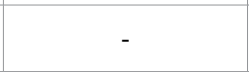 & serino proteinase, $\mathrm{Ca}^{2+}$ independent & $\begin{array}{l}\text { Alvarez Flores et } \\
\text { al. [33] }\end{array}$ \\
\hline \multirow{8}{*}{$\begin{array}{l}\text { Prothrombin (FII) } \\
\text { activators }\end{array}$} & Ecarin & Echis carinatus & $\begin{array}{c}56,000 \text { or } \\
72,000\end{array}$ & - & metalloproteinase, $\mathrm{Ca}^{2+}$ independent group $\mathrm{A}^{\mathrm{c}}$ & $\begin{array}{l}\text { Yamada et al. [71]; } \\
\text { Moore [72] }\end{array}$ \\
\hline & Insularinase A & Bothrops insularis & 22,639 & FX, fibrinogen, fibrin & metalloproteinase, group A & Modesto et al. [40] \\
\hline & Berythractivase & Bothrops erythromelas & 78,000 & - & metalloproteinase, group A & Silva et al. [41] \\
\hline & Carinactivase-1 & Echis carinatus & 87,000 & - & metalloproteinase $\mathrm{Ca}^{2+}$ dependent, group $\mathrm{B}$ & Yamada et al. [71] \\
\hline & Pseutarin C & Pseudonaja textilis & $\sim 250,000$ & - & $\begin{array}{l}\text { serino proteinase, dependent on } \mathrm{Ca}^{2+} \text { and phos- } \\
\text { pholipids, group } \mathrm{C} \text {, structurally and functionally } \\
\text { similar to the mammalian FXa-FVa complex }\end{array}$ & Rao and Kini [39] \\
\hline & Trocarin D & Tropidechis carinatus & 46,515 & - & $\begin{array}{l}\text { serino proteinase, dependent on } \mathrm{Ca}^{2+} \text {, phos- } \\
\text { pholipids and FVa group } \mathrm{D} \text {, structurally similar } \\
\text { to the mammalian FXa }\end{array}$ & Joseph et al. [42] \\
\hline & Textarin & Pseudonaja textilis & 53,000 & - & $\begin{array}{l}\text { serino proteinase, dependent on } \mathrm{Ca}^{2+} \text {, phos- } \\
\text { pholipids and FVa, group D }\end{array}$ & Stocker et al. [73] \\
\hline & Lopap & Lonomia obliqua & $\begin{array}{c}69,000 \text { or } \\
20,800\end{array}$ & - & $\begin{array}{l}\text { serino proteinase, its activity is enhanced by } \\
\mathrm{Ca}^{2+} \text { ions, structurally similar to lipocalin family } \\
\text { members }\end{array}$ & Reis et al. $[4,44,45]$ \\
\hline \multirow{3}{*}{ Factor $\mathrm{V}$ activators } & $R V V-V$ & $\begin{array}{l}\text { Vipera russelli } \\
\text { (Dabioa russeli) }\end{array}$ & 29,000 & - & serino proteinase & Kisiel [1] \\
\hline & LVV-V (VLFVA) & $\begin{array}{l}\text { Vipera lebetina } \\
\text { (Daboia lebetina) }\end{array}$ & 28,400 & - & serino proteinase & Siigur et al. [54] \\
\hline & Lonomin VI: a & Lonomia achelous & - & - & metalloproteinase & López et al. [59] \\
\hline \multirow{3}{*}{ Thrombin-like } & Ancrod (Arvin) & $\begin{array}{l}\text { Calloselasma rhodos- } \\
\text { toma (Agkistrodon } \\
\text { rhodostoma) }\end{array}$ & $\begin{array}{c}48,000 \\
\left(29,000^{d}\right)\end{array}$ & - & serine protease & $\begin{array}{l}\text { Burkhart et al. [94]; } \\
\text { Yu et al. [93] }\end{array}$ \\
\hline & $\begin{array}{l}\text { Batroxobin } \\
\text { (Reptilase or } \\
\text { Defibrase) }\end{array}$ & $\begin{array}{l}\text { Bothrops atrox } \\
\text { (Bothrops moojeni) }\end{array}$ & $\begin{array}{c}29,100 \\
\left(25,503^{d}\right)\end{array}$ & - & serine protease & $\begin{array}{l}\text { Marsh [78]; Vu et } \\
\text { al. [86] }\end{array}$ \\
\hline & Thrombocytin & Bothrops atrox & 36,000 & $\begin{array}{l}\text { prothrombin, FXIII, } \\
\text { FVIII and platelets }\end{array}$ & serine protease & $\begin{array}{l}\text { Niewiarowski et al. } \\
\text { [61]; Glusa et al [62] }\end{array}$ \\
\hline
\end{tabular}

aSome molecules can display more than one function.

${ }^{\mathrm{b}}$ The given references may not be of the first author to describe the respective molecules.

${ }^{\mathrm{c}}$ According to the classification of Kini (2005)

${ }^{\mathrm{d} B}$ Based on amino acid composition without carbohydrate content

Table 1: Biochemical properties of procoagulant proteins from snake and arthropod venoms.

classes. However, there are prothrombin activators that present particular properties and do not fit properly into any of the four classes, e.g. the Lonomia obliqua prothrombin activator protease (Lopap) [4].

Insularinase $\mathrm{A}$ is a single-chain $23 \mathrm{kDa}$ proteinase purified from Bothrops insularis venom. Insularinase A converts prothrombin into meizothrombin independent of the prothrombinase complex, and can also activate FX and hydrolyze fibrinogen and fibrin. cDNA sequence analysis revealed that the disintegrin domain of the precursor protein is post-translationally processed, producing mature Insularinase A [40].

Berythractivase is a non-hemorrhagic prothrombin activator from Bothrops erythromelas snake venom, belonging to group A. It is a single-chain metalloproteinase of $78 \mathrm{kDa}$, which is also capable of hydrolyzing fibrinogen A $\alpha$-chain and triggering endothelial proinflammatory and procoagulant cell responses. This toxin also induces the release of von Willebrand factor (vWF) and expression of cell adhesion molecules in endothelial cells. Its complete sequence has been reported and cDNA cloned from B. erythromelas venom-gland.
Berythractivase contains three distinct domains: metalloproteinase, desintegrin-like and cysteine-rich domains, and it is similar to other snake venom metalloproteinases [41].

Trocarin D is a highly expressed toxin in the venom of the snake Tropidechis carinatus [42]. This protein belongs to the group D prothrombin activator, structurally similar to mammalian FX, and the structure was characterized from its gene by Reza [43]. It is a $47-\mathrm{kDa}$ glycoprotein that has a light chain with $\mathrm{N}$-terminal gammacarboxyglutamic (Gla) domain, two EGF-like domains; and a heavy chain that consists of a serine proteinase domain. Its complete amino acid sequence has been previously reported [42].

Lopap is a prothrombin activator from the venom of Lonomia obliqua moth caterpillar with serine proteinase-like activity [44], which does not fit in the current classification of snake venom prothrombin activators [36]. It is able to activate prothrombin in the absence of the prothrombinase complex. It has its activity enhanced by calcium ions and generates $\alpha$-thrombin without the intermediate meizothrombin [45]. Lopap monomer has a molecular mass of $20 \mathrm{kDa}$ 
and its sequence is not similar to other known sserine proteinase or prothrombin activators, but it is structurally similar to members of the lipocalin family. It is the first lipocalin presenting proteolytic activity [4]. This protein has been characterized in vitro and in vivo, and plays an important function in the consumptive coagulopathy caused by $L$. obliqua envenomation $[44,45]$. This toxin also triggers various responses in endothelial cells and displays antiapoptotic activity. Recently our research group have shown that rLopap is able to reverse the bleeding induced by LMWH in vivo $[9,46,47]$.

Factor X activators: The physiological activators of FX are FIXa, in the intrinsic pathway, and FVIIa-TF, in the extrinsic pathway. FIXa can form a catalytic complex, called factor X-activating complex or tenase complex, in the presence of calcium ions, FVIIIa and phospholipids. FX activation by FIXa in this complex is accelerated 24 millionfold [34]. Despite the fact that many FX activator enzymes have been reported in the venom of various snake species, only a limited number has been isolated and characterized, and most of them as being metalloproteinases from snakes of the Viperidae and Crotalidae families [48]. A few serine proteinase FX activators were described in Elapidae venom [49], and only one was reported from a lepidopter [33].

The complete amino acid sequence analysis was reported for two metalloproteinases, RVV-X (Russell's viper venom factor $\mathrm{X}$ activator) [50] and VLFXA (Vipera lebetina factor X activator) [51]. Both proteins are glycosilated and show disintegrin-like, cystein-rich and metalloproteinase domain in the heavy chain. Also, they have C-type lectin domains in two light chains. The heavy and light chains are linked by disulfide bonds [50]. According to Tans and Rosing [48], the exogenous FX activators from snake venom can be classified according to the molecular mass, the number of subunits (polypeptide chains), and the susceptibility to proteinase inhibitors. Generally, there are two distinguished groups of FX activators, metalloproteinase and serine proteinase activators. The activators of the metalloproteinase are structurally and functionally similar to RVV-X. These RVVX-like enzymes have three subunits held together by disulfide bonds and require calcium ions for their activity. On the other hand, the activators of the serine proteinase correspond to single-chain proteins, strongly dependent on calcium as the RVVX-like activators.

RVV-X was the first identified FX activator, which was purified from the venom of Vipera russelli (Daboia russelli) [52]. RVV-X is also capable to activate FIX. In 1997, the crystal structure of RVV-X was determined [53].

The VLFXA was purified from Vipera lebetina venom [54] and its amino acid sequence was deduced from the nucleotide sequences of cDNAs encoding the light and heavy chains, which are synthesized from different genes. VLFXA was the first FX activator who's heavy and light chains were cloned [51]. Besides cleaving the $\mathrm{Arg}^{52}-\mathrm{Ile}^{53}$ bond in the heavy chain of FX, VLFXA is able to cleave the $\mathrm{Arg}^{226}-\mathrm{Val}^{227}$ bond in human FIX precursor. VLFXA could not activate prothrombin, and did not have any effect on fibrinogen. It had no arginine esterase activity toward benzoylarginine ethyl ester [54].

From lepidopters, the first identified FX activator was named Losac (Lonomia obliqua Stuart-factor activator). It consists of a $45-\mathrm{kDa}$ serine proteinase purified from the bristles of the Lonomia obliqua moth caterpillar, which is able to activate FX in absence of calcium [33], unlike the other snake venom FX activators, which request calcium ions for their activity [48]. Besides its procoagulant activity, this protein also functions as a growth stimulator of endothelial cells and is an inhibitor of apoptosis by inducing the liberation of nitric oxide and tPA $[33,55,56]$

Factor V activators: Thrombin is the physiological activator of FV, as well as FXa [57]. Exogenous FV activators can be found in the venoms of snakes from the families Crotalidae (Bothrops atrox), Elapidae (Naja naja oxiana) and Viperidae (Vipera russelli, Vipera lebetina, Vipera ursini), and in the hemolymph of Lonomia achelous caterpillar. All of them have serine proteinase-like activity [58], except for the activator from caterpillar, which is a metalloproteinase [59]. The FV activators from the venoms of Vipera russelli (RVV-V) and Vipera lebetina (LVV-V) are single-chain proteinase of 26 and 28 $\mathrm{kDa}$, respectively. These toxins had their three-dimensional structure models predicted and their mechanism of activation of FV compared to human $\alpha$-thrombin [60]. RVV-V and LVV-V activate FV by cleavage in a single peptide bond, in contrast to endogenous activation by thrombin, which cleavages three peptide bonds $[58,60]$.

Thrombin-like enzymes: Thrombin is a multifunctional enzyme, which plays a key role in the coagulation system, because it directly converts circulating fibrinogen to an insoluble fibrin clot. Thrombinlike enzymes are a group of toxins with serine proteinase-like activity able to clot fibrinogen. They are functionally and structurally related to thrombin, and are present in the venoms of several species of snakes from the families Viperidae and Colubridae [25]. Like thrombin, thrombin-like toxins can be multifunctional enzymes. There are thrombin-like enzymes reported to have FV activator activity [58], such as Thrombocytin from Bothrops atrox venom, which can also hydrolyze prothrombin, activate FXIII, FVIII and platelets [61], and cause an endothelium-dependent relaxation on arteries [62]. Despite most snake venom thrombin-like enzymes that only hydrolyze fibrinogen and have no effect on the other clotting factors, some thrombin-like toxins have shown activity in nervous and complement systems [25]. Castro et al. [25] have reviewed the structural and functional features of thrombin-like enzymes. In addition, some reports have shown the molecular cloning, phylogeny, as well as structural, biochemical and biological characterization of thrombin-like toxins [63].

As previously discussed, thrombin-like enzymes display procoagulant activity by converting fibrinogen to fibrin, but in vivo they can induce an anticoagulant effect by causing fibrinogen depletion [64,65]. In contrast to fibrin(ogen)olytics enzymes that usually cleave fibrinogen on the C-terminal portion hindering clot formation, thrombin-like enzymes hydrolyze fibrinogen at the N-terminal end of the $A \alpha$ and/or $B \beta$ chain, releasing relatively small portions of the fibrinogen molecule, called fibrinopeptides A and B, respectively [25]. These cleavages in the fibrinogen molecule allow its polymerization, with the formation of the fibrin clot [66]. However, in contrast to thrombin, the majority of the thrombin-like enzymes from snake venoms preferentially releases only fibrinopeptide $\mathrm{A}$ or $\mathrm{B}$, resulting in the formation of abnormal fibrin clots, and some of them are not able to activate FXIII [67], necessary to form insoluble and cross-linked fibrin clots. Consequently, these enzymes form an instable fibrin clot, which is easily removed by the fibrinolytic system [68]. Two wellcharacterized thrombin-like enzymes, Ancrod and Batroxobin, are currently used therapeutically as defibrinogenating agents [64].

Thrombin-like enzymes are present on snake venoms; in contrast, at the moment it was not yet described thrombin-like enzymes from Lonomia venoms.

\section{Exogenous Procoagulant Factors as Reagents for Diagnostic Tests}


To date, the most important application for procoagulant toxins is in the area of diagnosis. Several toxins have been proved to be useful as reagents in laboratory tests for diagnosis, for example, to detect clotting factor deficiencies and to monitor patients undergoing anticoagulant therapy [7]. The diagnostic uses of snake venom toxins have been reviewed by different authors [7,69,70]. Prothrombin activators have a wide range of applications; they have been used for prothrombin assays, to detect dysprothrombinemias, disseminated intravascular coagulation and to assay PIVKA-II (protein induced by vitamin $\mathrm{K}$ absence or antagonist-II). PIVKA-II or des-gamma carboxyprothrombin is a non-functional prothrombin precursor, which accumulates during therapy with vitamin $\mathrm{K}$ antagonists, and is also a biomarker of hepatocellular carcinoma. Group A prothrombin activators, such as Ecarin, can cleave the descarboxy variety of prothrombin, because these enzymes act independently of calcium ions [71]. Therefore, these enzymes are not indicated to monitor patients' anticoagulated with vitamin $\mathrm{K}$ antagonists.

The procoagulant activity in plasma exerted by prothrombin activators can be affected by Hirudin, a thrombin inhibitor from leech saliva that is used as anticoagulant medication. In contrast, heparin and lupus anticoagulant cannot affect the procoagulant activity of these enzymes. Thus, prothrombin activators such as Ecarin are commonly used in laboratory tests (e.g. Ecarin clotting time) to monitor patients under treatment with Hirudin. In addition, Ecarin time has been proposed to be used in association with Taipan snake venom time to detect lupus anticoagulant in patients receiving oral anticoagulant therapy [72].

Textarin, a group $\mathrm{D}$ prothrombin activator has been also suggested as a reagent for the detection of lupus anticoagulant [73]. This enzyme is used in a test denominated Textarin time assay, to detect resistance to activated protein C (APC-resistance), which is frequently associated with a single point mutation in the FV gene, known as Factor V Leiden [74]. In this coagulation disorder, FVa is resistant to inactivation by APC, implicating in a thrombotic risk for the patient (thrombophilia) [75]. Therefore, the ratio of prolongation of clotting time in the presence of APC is less pronounced in the plasma from APC resistant patients [74]. There are a variety of prothrombin activators from the venoms of the Australian brown snake Pseudonaja textilis (Textarin), the saw-scaled viper Echis carinatus (Ecarin), the mainland Australian tiger snake Notechis scutatus scutatus (Noscarin), and the Taipan snake Oxyuranus scutellatus that are commercially available [68].

Among the snake venom FV activators commercially available, the $\mathrm{RVV}-\mathrm{V}$, a toxin from Russell's viper venom is one of the most used. $\mathrm{RVV}-\mathrm{V}$ is the key reagent of different diagnostic kits. One of them is a clotting test based on the prothrombinase complex, and is used to monitor patients undergoing anticoagulant therapy, except for vitamin $\mathrm{K}$ antagonists. In presence of $\mathrm{RVV}-\mathrm{V}$ the prothrombinase complex is formed very quickly, generating active thrombin that cleaves fibrinogen to fibrin. Another kit using RVV-V is applied to detect Factor V Leiden mutation genotype. This test consists of two steps, one involving the activation of FV by RVV-V followed by inactivation of FVa by the addition of APC. In the second step, the group D prothrombin activator Noscarin is added to generate active thrombin and finally the fibrin clot. Since Noscarin activity is dependent of FVa as a cofactor, patients with Factor V Leiden mutation have short clotting times in comparison with normal individuals [7]. Another toxin from Russell's viper venom, RVV-X is a FX activator also used for diagnostic tests, for detection of factor X deficiency [76] and lupus anticoagulant [77], which is another important risk factor for thrombophilia. A commonly used assay to detect lupus anticoagulant is the dilute Russell's viper venom time dRVVT, which is based on the activity of RVV-X [70,77]. There are various kits commercially available to assay dRVVT, which contain purified RVV-X or the whole venom from Russell's viper [70,77].

Thrombin-like enzymes from snake venoms are not inhibited by heparin, but they are used for detecting dysfibrinogenemias and to remove fibrinogen for different assays [78]. Batroxobin, a thrombinlike enzyme from Bothrops moojeni or Bothrops atrox, is used in the diagnostic procedures and test kits, such as the Reptilase time [7].

\section{Exogenous procoagulant factors as therapeutic agents}

Unlike thrombin, which cleaves both fibrinopeptide A (FPA) and fibrinopeptide B (FPB) from fibrinogen, many thrombin-like enzymes usually only cleave FPA and do not activate FXIII. This aspect makes the thrombin-like enzymes interesting tools to remove fibrinogen from plasma (defibrinogenation) without the risk of thrombosis, because the fibrin clot formed is very unstable in contrast to cross-linked fibrin [68]. Therefore, the fibrin is rapidly removed by the fibrinolytic system. Otherwise, administration of a thrombin-like enzyme as a defibrinogenating agent has a low bleeding risk in comparison to other anticoagulants that have been used [24]. Among the procoagulant proteins from animal venoms currently in use as therapeutic tools, the most relevant are the thrombin-like enzymes. Ancrod is a serine proteinase toxin from a Malayan pit viper snake Agkistrodon rhodostoma (Calloselasma rhodostoma) [79] that cause reduction in plasma fibrinogen concentration in vivo by formation of soluble fibrin complexes, which are degraded by plasmin. Also, it induces plasminogen activation and leads to a fibrinolytic response [80].

Ancrod and Batroxobin, which are also commercially named Arvin and Defibrase, respectively, are indicated as defibrinogenating drugs to patients with stroke, deep vein thrombosis, myocardial infarction, peripheral arterial thrombosis, priapism, and sickle-cell crisis $[64,81,82]$.

In a large-scale trial utilizing Ancrod (Arvin), for example, a higher proportion of patients achieved good functional outcomes when the drug was given within $3 \mathrm{~h}$ of stroke onset and continued for five days compared to placebo [83]. However, the phase III trials were terminated because they showed that giving the drug to patients within $6 \mathrm{~h}$ of stroke onset was ineffective [84]. Therefore, the dosing regimen appears to be an important criterion for successful outcomes in the use of these defibrinogenating agents.

The thrombin-like enzymes can be used as procoagulants for hemorrhage management. A mixture of two enzymes from the venom of $B$. atrox, $a$ thrombin-like enzyme and a thromboplastin-like enzyme, form a clot-promoting product called Haemocoagulase ${ }^{\circledR}$. These enzymes cooperate, targeting different points at the coagulation cascade to form blood clots. The thrombin-like enzyme directly cleaves fibrinogen into fibrin monomers, and the thromboplastin-like enzyme activates FX, which in turn converts prothrombin into thrombin [69]. Batroxobin is a component present on venom from $B$. atrox moojeni that acts as thrombin-like enzyme $[81,82,85]$. This serine proteinase only releases fibrinopeptide A by specific cleavage of $\mathrm{Arg}^{16}$-Gly ${ }^{17}$ bond in the A $\alpha$-chain of fibrinogen, and it is not inhibited by antithrombin or heparin cofactor II $[82,86]$.

In another therapeutic field, defibrinogenting agents may be used as a hemostatic agent to arrest bleeding, for example, during surgical procedures. The hemostatic reagents, which have been available for 
over the last fifty years and are still currently used for these purposes, include absorbable gelatin sponge, oxidized cellulose, microfibrillar collagen and thrombin, which act by forming an artificial clot or by producing a mechanical matrix that facilitate clotting when applied directly to denuded or bleeding surfaces [87]. A fibrinogen-thrombincollagen-based material has been demonstrated to be advantageous because it is quickly available and easily applicable, but there are disadvantages inherent to exogenous fibrinogen and thrombin sources, which might be potentially infectious, and a rigorous control of several types of contamination would become necessary [88]. Therefore, development of hemostatic agents based on exogenous procoagulant factors would be an interesting approach. In addition, research on possible antidotes for the currently available anticoagulants should also be an interesting issue, especially in the cases of bleeding risk and surgical procedures. Recent studies have showed the recombinant form of the prothrombin activator isolated from Lonomia obliqua (rLopap), [4] as a first exogenous prothrombin activator capable of reversing bleeding induced by LMWH [9].

Table 2 shows some exogenous procoagulant factors as diagnostic test reagents and therapeutic drugs.

\section{The non-hemostatic effects of exogenous hemostatic}

\section{factors}

Endogenous coagulation and fibrinolytic factors can trigger effects not directly related to blood coagulation and fibrinolysis, such as effects related to inflammation, homeostasis and cell responses. Accordingly, an increasing number of studies have demonstrated non-hemostatic actions displayed by molecules characterized as exogenous hemostatic factors.

The involvement of endogenous hemostatic factors was demonstrated in the cell regulation, cancer, angiogenesis, nervous system [89]. They can display various biological activities, hemostatic and non-hemostatic [32]. Exogenous hemostatic factors can modulate the endothelial cell responses, the release and synthesis of bioactive substances, the gene expression, the cell signaling, the cell adhesion, apoptosis, the proliferation and inflammatory reactions [90-92]. Two procoagulant proteins, Insularinase $A$ and Lopap, have increased the levels of nitric oxide and prostacyclin released by endothelial cells, for instance [40,47]. In addition, Losac and Lopap have shown antiapoptotic activities [33,47]. Trocarin D, a well-characterized prothrombin activator from snake venom, can also trigger nonhemostatic roles [90]. Besides its procoagulant action, Losac stimulated in endothelial cells the release of tissue plasminogen activator (t-PA), and nitric oxide (NO), a potent vasodilator [33]. NO may also inhibit apoptosis in endothelial cells [93] and t-PA has also the ability to promote cell proliferation independent of plasmin generation [94]. Thus, it is possible that t-PA and NO may be indirectly involved in Losac-induced cell proliferation and viability. On the other hand, the role of Losac-induced t-PA release in the hyperfibrinolytic state observed in patients was not yet fully explored.

Analysis of gene expression in fibroblasts has shown that L. obliqua venom up-regulated the expression of genes involved in hemostasis, including tissue factor, a component of the tenase complex whose final product is thrombin, and the urokinase plasminogen activator (u-PA) receptor [95]. On the other hand, Losac induced in endothelial cells the up-regulation of transcription factors involved in cell proliferation and inhibition of apoptosis (unpublished data). Thus, there are a relationship between up-regulation of hemostasis by L. obliqua venom and modulation of cell proliferation and cell survival.

In the last years, biochemical and molecular methods have provided new insights about the interaction of blood coagulation with other processes, such as cell proliferation, tissue repair and angiogenesis [96] It is well known that the activation of blood coagulation in response to tissue injury leads to thrombin formation which in turn induces the conversion of pro-hepatocyte growth factor (HGF) into active HGF for subsequent repair of damaged blood vessels [97]. Structurally, HGF is homologous to plasminogen and may be activated by the factor XIIa and by the plasminogen activators u-PA and t-PA [98]. It is noteworthy to mention that HGF was also associated with hypercoagulable conditions, such as disseminated intravascular coagulation (DIC) by multiples mechanisms [99]. Factor $\mathrm{Xa}$ and pro-inflammatory cytokines were reported to release soluble HGF from stromal cells and granulocytes [100]. HGF binds to its receptor in endothelial cells and activates cell signals leading to endothelial cell growth/migration and inhibition of apoptosis [101]. Moreover, HGF induces the expression of tissue factor and regulates gene transcription of plasminogen activator inhibitor 1 (PAI-1) and cyclooxygenase 2 (COX-2) [99, 102]. COX-2 expressed by HGF inhibits anoikis, the apoptotic process induced by loss of matrix attachment [103].

Thus, the ability of L. obliqua venom to activate blood coagulation

\begin{tabular}{|c|c|c|c|c|c|c|}
\hline & Procoagulant factor & Main target & Application & Commercial names & Characteristic & Reference $^{a}$ \\
\hline \multirow{5}{*}{$\begin{array}{l}\text { Diagnostic } \\
\text { tests }\end{array}$} & Ecarin & prothrombin & Clotting time assay & Tirofiban & Prothrombin activator & Moore [72] \\
\hline & Textarin & prothrombin & $\begin{array}{l}\text { Lupus anticoagulant } \\
\text { Factor V Leiden Disease }\end{array}$ & & Prothrombin activator & Stocker [73] \\
\hline & Noscarin & prothrombin & Factor V Leiden Disease & & Prothrombin activator & Marsh and Williams [68] \\
\hline & $R V V-X$ & $\mathrm{FX}$ & $\begin{array}{l}\text { Factor X deficiency } \\
\text { Lupus anticoagulant }\end{array}$ & $R V V-X$ & Factor $\mathrm{X}$ activator & $\begin{array}{l}\text { Bezeaud et al. [76]; } \\
\text { Triplett [77] }\end{array}$ \\
\hline & RVV-V & FV & $\begin{array}{l}\text { Clotting time assay } \\
\text { Factor V Leiden Disease }\end{array}$ & RVV-V & Factor $\mathrm{V}$ activator & Schöni [7] \\
\hline \multirow{4}{*}{$\begin{array}{l}\text { Clinical } \\
\text { therapy }\end{array}$} & Ancrod & Fibrinogen & Defibrinogenating agents & Viprinex & Thrombin-like & Bell [64] \\
\hline & Batroxobin & Fibrinogen & Defibrinogenating agents & Reptilase; Defibrase & Thrombin-like & $\begin{array}{l}\text { Bell [64]; Qin et al. [81]; } \\
\text { Serrano [82] }\end{array}$ \\
\hline & rLopap & Prothrombin & Bleeding reversor & & Prothrombin activator & Andrade et al. [9] \\
\hline & & $\begin{array}{l}\text { Fibrinogen and } \\
\text { Factor } X\end{array}$ & Procoagulant for hemorrhage & Haemocoagulase & $\begin{array}{l}\text { Mixture: Thrombin-like and } \\
\text { thromboplastin like enzyme }\end{array}$ & McCleary and Kini [69] \\
\hline
\end{tabular}

aThe given references may not be of the first author to describe the respective molecules

Table 2: Exogenous procoagulant factors as diagnostic test reagents and therapeutic drugs. 
raises the possibility that mediators such as HGF, t-PA, NO and COX2 may also regulate the processes that involve cell proliferation, cell survival and tissue repair. On the other hand, other studies will be carried out aiming to shed light on the pathophysiological mechanism of the envenoming by $L$. obliqua allowing the identification of mediators, such as HGF, and its involvement in the hyperfibrinolytic state, a disturbance observed in patients and that remain, however, non-elucidated.

Thus, the comprehension of the multi-faced physiological roles of exogenous factors can be helpful to better understand and treat the envenoming and bring new perspectives for therapeutic and biotechnological approaches.

\section{Limitations of Exogenous Procoagulant Factors in Diagnostic and Therapeutic}

The development of hemostatic agents based on exogenous procoagulant factors became an interesting approach for applications in health and biotechnology, but a number of limitations deserve mention. The complexity of some molecules makes still difficult the purification and recovery of these toxins from the venom maintaining the same biological activities, especially enzymatic. Contaminations with other venom factors could result in toxic effects. It has to be taken into consideration the use of recombinant toxins as tools for health care and biotechnology. There are publications describing the production of recombinant Batroxobin [104] and Ancrod [105] in Pichia pastoris, an organism which is currently being elected for the expression of recombinant proteins with therapeutic purposes, due to various advantages, such as cost-effectivity and easy up scaling, in comparison to prokaryotic systems and Saccharomyces [106]. However, biochemical, biophysical and pharmacological properties of a recombinant protein may not completely be the same as their native form, which means that it may not have the same rate of activity.

Some proteins, such as Ancrod [105], have been clinically used in its native form, but the majority of procoagulant snake venom toxins have been used as reagents in laboratory tests and diagnostic kits [107]. The use of exogenous factors as therapeutic products need the approvals of several regulatory procedures that delay the time between research, development and production; not to mention the costs and efforts involving intellectual property.

The research and development involving the use of procoagulant proteins are incipient in comparison to the current status of the use of exogenous inhibitors in the therapeutic field. One of the reasons is the management and unpredictable effects of its enzymatic activity in the organism, in addition to the immunogenic potential. Ancrod treatment effectively reduce blood viscosity by inducing defibrination, but repeated intravenous or subcutaneous administration of Ancrod caused biological resistance in mammal, specially humans, due its antigenic nature [108]. Some approach were used to minimize the antigenic effects such as, oral administration of Ancrod delivered into a hydrogel capsule based on polyethylene glycol (PEG) [109]. Subsequently, Ancrod failed in several clinical trials for acute ischemic stroke [110-111], probably due to Ancrod-induced fibrin and reduced levels of t-PA in microvascular endothelium that could result in cerebral microvascular occlusion [112]. Unlike Ancrod, Bathroxobin was well successful for deep vein thrombosis [113].
Identification of new targets and new effects for the exogenous factors already described can open new perspectives, or the modification of the molecule based on functional and structural regions, for example the removal of the enzymatic activity when undesired to avoid a specific effect or the design and synthesis of short peptides to minimize toxic and side effects, all these are interesting task.

\section{Concluding Remarks and New Perspectives}

To date, the largest applications of procoagulant snake venom toxins have been their used as reagents in laboratory tests and diagnostic kits [7]. Probably, this is due to potential risks associated to toxicity and immunogenicity of the clinical use of these proteins as therapeutic agents. In addition, the need for several regulatory procedures and approvals for the development of therapeutic drugs, and the high costs associated to research, development and production, can direct the preferences for the use of exogenous hemostatic factors as diagnostic instead of therapeutic tools. It has to be taken into consideration that biochemical, biophysical and pharmacological properties of a recombinant protein might not be completely the same as its native form, reflecting on the biological activity. Numerous procoagulant proteins have been isolated in their native form from animal venoms, mainly from snakes. They have been sequenced and cloned, but the majority has not been functionally expressed as recombinant molecules. However, many efforts have been currently applied in this sense.

Opportunely, the number of studies dedicated to the production of recombinant proteins as tool for health care and biotechnology has risen over the last few years. For example, there are publications reporting the production of recombinant Batroxobin [114] and Ancrod [115-116] in Pichia pastoris, a yeast vector. Pichia pastoris is now being elected for the expression of recombinant proteins with therapeutic purposes due to advantages as the presence of a post translational modification machinery, which is absent in prokaryotic expression systems, and the cost-effectiveness and easy-to-assemble cultivation system suitable for up scaling in comparison to E. coli and Saccharomyces [117]. Other exogenous procoagulant proteins that have been functionally expressed as recombinant molecules are the prothrombin activators from the snake Pseudonaja textiles [118] and from the Lonomia obliqua caterpillar (Lopap) [4], respectively.

The research and development involving the use of procoagulant proteins are still incipient in comparison to the use of exogenous inhibitors in the therapeutic field. One of the reasons could be the management and unpredictable effects of its enzymatic activity in the human organism, in addition to its immunogenic potential. Although several toxins that act as activators or inhibitors in the hemostatic system have been described and well characterized, much have to be investigated regarding their other possible roles in the organism. These biological effects are currently under investigation for various toxins from different poisoning species, and can provide additional data related to the understanding of the complex reactions involved in poisoning. The multi-faced physiological action of endogenous and exogenous factors can be explained by a converging evolution of distinct activities in a same molecule, or a common molecular evolutive origin [25]. In the case of exogenous factors, the structure-function relationship suggests that a molecule with intrinsic roles for the animal could have acquired another function, which would provide advantages for animal defense, attack or feeding purposes, for instance [119].

The knowledge about the non-hemostatic effects of the exogenous factors can point out new targets for disease control and therapy, and 
Citation: Chudzinski-Tavassi AM, Carrijo-Carvalho LC, Alvarez-Flores MP, Andrade SA (2014) Exogenous Procoagulant Factors as Therapeutic and Biotechnological Tools. J Blood Disorders Transf 5: 209. doi: 10.4172/2155-9864.1000209

concomitantly bring new perspectives for the use of these proteins in the study and treatment of a wide range of dysfunctions. In this regard, studies of site-directed mutagenesis and sequence mapping can be considered as an interesting tool, allowing the removal of undesired enzymatic activities. In addition, the diversity of known exogenous factors and the innumerous recently identified also suggest that there are many other molecules to be discovered, which could belong to the established classes or even present new biochemical properties.

\section{Acknowledgement}

The authors were supported by fellowships from Brazilian Agencies, São Paulo Research Foundation - FAPESP (to L.C.C.C., grant 2005/59739-9, to A.M.C.T., grant 2013/07467-1 and 2013/06892-0) and CNPq (to A.M.C.T).

\section{References}

1. Kisiel W (1979) Molecular properties of the Factor V-activating enzyme from Russell's viper venom. J Biol Chem 254: 12230-12234.

2. Carrijo-Carvalho LC1, Chudzinski-Tavassi AM (2007) The venom of the Lonomia caterpillar: an overview. Toxicon 49: 741-757.

3. Kini RM (2011) Evolution of three-finger toxins - a versatile mini protein scaffold Acta Chim Slov 58: 693-701.

4. Reis CV, Andrade SA, Ramos OHP, Ramos CRR, Ho PL, et al. (2006) Lopap, a prothrombin activator from Lonomia obliqua belonging to the lipocalin family: recombinant production, biochemical characterization and structure-function insights. Biochem J 398: 295-302.

5. Ricci-Silva ME, Valente RH, León IR, Tambourgi DV, Ramos OH, et al. (2008) Immunochemical and proteomic technologies as tools for unravelling toxins involved in envenoming by accidental contact with Lonomia obliqua caterpillars. Toxicon 51: 1017-1028.

6. Batista IF, Chudzinski-Tavassi AM, Faria F, Simons SM, Barros-Batestti DM, et al. (2008) Expressed sequence tags (ESTs) from the salivary glands of the tick Amblyomma cajennense (Acari: Ixodidae). Toxicon 51: 823-834.

7. Schoni R (2005) The use of snake venom-derived compounds for new functional diagnostic test kits in the field of haemostasis. Pathophysiol Haemost Thromb 34: 234-240.

8. Clemetson KJ, Lu Q, Clemetson JM (2007) Snake venom proteins affecting platelets and their applications to anti-thrombotic research. Curr Pharm Des 13: $2887-2892$

9. Andrade SA, Carrijo-Carvalho LC, Peceguini LA, Wlian L, Sato AC, et al. (2012) Reversal of the anticoagulant and anti-hemostatic effect of low molecular weight heparin by direct prothrombin activation. Braz J Med Biol Res 45: 929-934

10. Veiga AB, Blochtein B, Guimarães JA (2001) Structures involved in production, secretion and injection of the venom produced by the caterpillar Lonomia obliqua (Lepidoptera, Saturniidae). Toxicon 39: 1343-1351.

11. Chudzinski-Tavassi AM, Carrijo-Carvalho LC (2006) Biochemical and biological properties of Lonomia obliqua bristle extract. J Venom Anim Toxins incl Trop Dis 12: 156-171.

12. Zannin M, Lourenço DM, Motta G, Dalla Costa LR, Grando M, et al. (2003) Blood coagulation and fibrinolytic factors in 105 patients with hemorrhagic syndrome caused by accidental contact with Lonomia obliqua caterpillar in Santa Catarina, southern Brazil. Thromb Haemost 89: 355-364.

13. Han J, You D, Xu X, Han W, Lu Y, et al. (2008) An anticoagulant serine protease from the wasp venom of Vespa magnifica. Toxicon 51: 914-922.

14. White J (2005) Snake venoms and coagulopathy. Toxicon 45: 951-967.

15. Markland FS (1998) Snake venoms and the hemostatic system. Toxicon 36 $1749-1800$.

16. Diaz JH (2004) The global epidemiology, syndromic classification, management, and prevention of spider bites. Am J Trop Med Hyg 71: 239-250.

17. van den Berg CW, Gonçalves-de-Andrade RM, Magnoli FC, Tambourgi DV (2007) Loxosceles spider venom induces the release of thrombomodulin and endothelial protein $\mathrm{C}$ receptor: implications for the pathogenesis of intravascular coagulation as observed in loxoscelism. J Thromb Haemost 5: 989-995.

18. Carrijo LC, Andrich F, de Lima ME, Cordeiro MN, Richardson M, et al. (2005)
Biological properties of the venom from the scorpionfish (Scorpaena plumieri) and purification of a gelatinolytic protease. Toxicon 45: 843-850.

19. Imamura S, da Silva Vaz Junior I, Sugino M, Ohashi K, Onuma M (2005) A serine protease inhibitor (serpin) from Haemaphysalis longicornis as an antitick vaccine. Vaccine 23: 1301-1311.

20. Mans BJ, Neitz AW (2004) Adaptation of ticks to a blood-feeding environment: evolution from a functional perspective. Insect Biochem Mol Biol 34: 1-17.

21. Champagne DE (2004) Antihemostatic strategies of blood-feeding arthropods Curr Drug Targets Cardiovasc Haematol Disord 4: 375-396.

22. Rau JC, Beaulieu LM, Huntington JA, Church FC (2007) Serpins in thrombosis, hemostasis and fibrinolysis. J Thromb Haemost 5 Suppl 1: 102-115.

23. Hoffman M (2003) Remodeling the blood coagulation cascade. J Thromb Thrombolysis 16: 17-20.

24. Crowther MA, Warkentin TE (2008) Bleeding risk and the management of bleeding complications in patients undergoing anticoagulant therapy: focus on new anticoagulant agents. Blood 111: 4871-4879.

25. Castro HC, Zingali RB, Albuquerque MG, Pujol-Luz M, Rodrigues CR (2004) Snake venom thrombin-like enzymes: from reptilase to now. Cell Mol Life Sci 61: 843-856.

26. Wisner A, Braud S, Bon C (2001) Snake venom proteinases as tools in hemostasis studies: structure-function relationship of a plasminogen activator purified from Trimeresurus stejnegeri venom. Haemostasis 31: 133-140.

27. Swenson S, Markland FS Jr (2005) Snake venom fibrin(ogen)olytic enzymes Toxicon 45: 1021-1039.

28. Markland FS Jr, Swenson S (2013) Snake venom metalloproteinases. Toxicon 62: 3-18.

29. Larréché S, Mion G, Goyffon M (2008) [Haemostasis disorders caused by snake venoms]. Ann Fr Anesth Reanim 27: 302-309.

30. Monteiro RQ (2005) Targeting exosites on blood coagulation proteases. An Acad Bras Cienc 77: 275-280.

31. Kini RM (2005) Serine proteases affecting blood coagulation and fibrinolysis from snake venoms. Pathophysiol Haemost Thromb 34: 200-204.

32. Kini RM (2011) Toxins in thrombosis and haemostasis: potential beyond imagination. J Thromb Haemost 9 Suppl 1: 195-208.

33. Alvarez Flores MP, Fritzen M, Reis CV, Chudzinski-Tavassi AM (2006) Losac, a factor $X$ activator from Lonomia obliqua bristle extract: its role in the pathophysiological mechanisms and cell survival. Biochem Biophys Res Commun 343: 1216-1223.

34. Ahmad SS, London FS, Walsh PN (2003) The assembly of the factor X-activating complex on activated human platelets. J Thromb Haemost 1: 48-59.

35. Mann KG, Nesheim ME, Church WR, Haley P, Krishnaswamy S (1990) Surface-dependent reactions of the vitamin K-dependent enzyme complexes. Blood 76: 1-16.

36. Kini RM (2005) The intriguing world of prothrombin activators from snake venom. Toxicon 45: 1133-1145.

37. St Pierre L, Masci PP, Filippovich I, Sorokina N, Marsh N, et al. (2005) Comparative analysis of prothrombin activators from the venom of Australian elapids. Mol Biol Evol 22: 1853-1864.

38. Rao VS, Swarup S, Kini RM (2003) The nonenzymatic subunit of pseutarin C, a prothrombin activator from eastern brown snake (Pseudonaja textilis) venom, shows structural similarity to mammalian coagulation factor V. Blood 102: 1347-1354.

39. Rao VS, Kini RM (2002) Pseutarin C, a prothrombin activator from Pseudonaja textilis venom: its structural and functional similarity to mammalian coagulation factor Xa-Va complex. Thromb Haemost 88: 611-619.

40. Modesto JC, Junqueira-de-Azevedo IL, Neves-Ferreira AG, Fritzen M, Oliva $M L$, et al. (2005) Insularinase A, a prothrombin activator from Bothrops insularis venom, is a metalloprotease derived from a gene encoding protease and disintegrin domains. Biol Chem 386: 589-600.

41. Silva MB, Schattner M, Ramos CR, Junqueira-de-Azevedo IL, Guarnieri MC et al. (2003) A prothrombin activator from Bothrops erythromelas (jararaca-daseca) snake venom: characterization and molecular cloning. Biochem $\mathrm{J} 369$ 129-139. 
Citation: Chudzinski-Tavassi AM, Carrijo-Carvalho LC, Alvarez-Flores MP, Andrade SA (2014) Exogenous Procoagulant Factors as Therapeutic and Biotechnological Tools. J Blood Disorders Transf 5: 209. doi: 10.4172/2155-9864.1000209

42. Joseph JS, Chung MC, Jeyaseelan K, Kini RM (1999) Amino acid sequence of trocarin, a prothrombin activator from Tropidechis carinatus venom: its structural similarity to coagulation factor Xa. Blood 94: 621-631.

43. Reza MA, Swarup S, Kini RM (2005) Gene structures of trocarin D and coagulation factor $X$, two functionally diverse prothrombin activators from Australian rough scaled snake. Pathophysiol Haemost Thromb 34: 205-208.

44. Reis CV, Kelen EM, Farsky SH, Portaro FC, Sampaio CA, et al. (1999) A Ca++ activated serine protease (LOPAP) could be responsible for the haemorrhagic syndrome caused by the caterpillar Lonomia obliqua. L obliqua Prothrombin Activator Protease. Lancet 353: 1942.

45. Reis CV, Portaro FC, Andrade SA, Fritzen M, Fernandes BL, et al. (2001) A prothrombin activator serine protease from the Lonomia obliqua caterpillar venom (Lopap) biochemical characterization. Thromb Res 102: 427-436.

46. Chudzinski-Tavassi AM, Schattner M, Fritzen M, Pozner RG, Reis CV, et al. (2001) Effects of lopap on human endothelial cells and platelets. Haemostasis 31: $257-265$

47. Fritzen M, Flores MP, Reis CV, Chudzinski-Tavassi AM (2005) A prothrombin activator (Lopap) modulating inflammation, coagulation and cell survival mechanisms. Biochem Biophys Res Commun 333: 517-523.

48. Tans G, Rosing J (2001) Snake venom activators of factor X: an overview. Haemostasis $31: 225-233$.

49. Zhang $Y$, Xiong YL, Bon C (1995) An activator of blood coagulation factor $X$ from the venom of Bungarus fasciatus. Toxicon 33: 1277-1288.

50. Takeya H, Nishida S, Miyata T, Kawada S, Saisaka Y, et al. (1992) Coagulation factor $X$ activating enzyme from Russell's viper venom (RVV-X). A nove metalloproteinase with disintegrin (platelet aggregation inhibitor)-like and C-type lectin-like domains. J Biol Chem 267: 14109-14117.

51. Siigur E, Aaspõllu A, Trummal K, Tõnismägi K, Tammiste I, et al. (2004) Factor $X$ activator from Vipera lebetina venom is synthesized from different genes. Biochim Biophys Acta 1702: 41-51.

52. Kisiel W, Hermodson MA, Davie EW (1976) Factor X activating enzyme from Russell's viper venom: isolation and characterization. Biochemistry 15: 4901-4906.

53. Takeda S, Igarashi T, Mori H (2007) Crystal structure of RVV-X: an example of evolutionary gain of specificity by ADAM proteinases. FEBS Lett 581: 5859-5864.

54. Siigur E, Tõnismägi K, Trummal K, Samel M, Vija H, et al. (2001) Factor $X$ activator from Vipera lebetina snake venom, molecular characterization and substrate specificity. Biochim Biophys Acta 1568: 90-98.

55. Chudzinski-Tavassi AM, Alvarez Flores MP (2005) Exploring new molecules and activities from Lonomia obliqua caterpillars. Pathophysiol Haemost Thromb 34: $228-233$

56. Alvarez-Flores MP, Furlin D, Ramos OH, Balan A, Konno K, et al. (2011) Losac the first hemolin that exhibits procogulant activity through selective factor $X$ proteolytic activation. J Biol Chem 286: 6918-6928.

57. Orfeo T1, Brufatto N, Nesheim ME, Xu H, Butenas S, et al. (2004) The factor V activation paradox. J Biol Chem 279: 19580-19591.

58. Rosing J, Govers-Riemslag JW, Yukelson L, Tans G (2001) Factor V activation and inactivation by venom proteases. Haemostasis 31: 241-246.

59. López M, Gil A, Arocha-Piñango CL (2000) The action of Lonomia achelous caterpillars venom on human factor V. Thromb Res 98: 103-110.

60. Segers K, Rosing J, Nicolaes GA (2006) Structural models of the snake venom factor $V$ activators from Daboia russelli and Daboia lebetina. Proteins 64: 968-984.

61. Niewiarowski S, Kirby EP, Brudzynski TM, Stocker K (1979) Thrombocytin, a serine protease from Bothrops atrox venom. 2. Interaction with platelets and plasma-clotting factors. Biochemistry 18: 3570-3577.

62. Glusa E, Brauns H, Stocker K (1991) Endothelium-dependent relaxant effect of thrombocytin, a serine proteinase from Bothrops atrox snake venom, on isolated pig coronary arteries. Toxicon 29: 725-732.

63. Sant'Ana CD, Bernardes CP, Izidoro LF, Mazzi MV, Soares SG, et al. (2008) Molecular characterization of BjussuSP-I, a new thrombin-like enzyme with procoagulant and kallikrein-like activity isolated from Bothrops jararacussu snake venom. Biochimie 90: 500-507.

64. Bell WR Jr (1997) Defibrinogenating enzymes. Drugs 54 Suppl 3: 18-30.
65. Maruñak SL, Acosta OC, Leiva LC, Ruiz RM, Aguirre MV, et al. (2004) Mice plasma fibrinogen consumption by thrombin-like enzyme present in rattlesnake venom from the north-east region of Argentina. Medicina (B Aires) 64: 509-517.

66. Colman RW, Marder VJ, Salzman EW, Hirsh J (1994) Overview of hemostasis In: Colman RW, Hirsh J, Marder VJ, Salzman EW, (Eds.), Hemostasis and Thrombosis: Basic Principles and Clinical Practice (3rd Edn.), Philadelphia: J.B. Lippincott, 3-18.

67. Matsui T, Fujimura Y, Titani K (2000) Snake venom proteases affecting hemostasis and thrombosis. Biochim Biophys Acta 1477: 146-156.

68. Marsh N, Williams V (2005) Practical applications of snake venom toxins in haemostasis. Toxicon 45: 1171-1181.

69. McCleary RJ, Kini RM (2013) Snake bites and hemostasis/thrombosis. Thromb Res 132: 642-646.

70. Moore GW (2014) Recent guidelines and recommendations for laboratory detection of lupus anticoagulants. Semin Thromb Hemost 40: 163-171.

71. Yamada D, Sekiya F, Morita T (1996) Isolation and characterization of carinactivase, a novel prothrombin activator in Echis carinatus venom with a unique catalytic mechanism. J Biol Chem 271: 5200-5207.

72. Moore GW (2007) Combining Taipan snake venom time/Ecarin time screening with the mixing studies of conventional assays increases detection rates of lupus anticoagulants in orally anticoagulated patients. Thromb J 5: 12.

73. Stocker K, Hauer H, Müller C, Triplett DA (1994) Isolation and characterization of Textarin, a prothrombin activator from eastern brown snake (Pseudonaja textilis) venom. Toxicon 32: 1227-1236.

74. Hoagland LE, Triplett DA, Peng F, Barna L (1996) APC-resistance as measured by a Textarin time assay: comparison to the APTT-based method. Thromb Res 83: $363-373$

75. De Stefano V, Leone G (1995) Resistance to activated protein C due to mutated factor $V$ as a novel cause of inherited thrombophilia. Haematologica 80: 344-356.

76. Bezeaud A, Miyata T, Helley D, Zeng YZ, Kato H, et al. (1995) Functional consequences of the Ser334-->Pro mutation in a human factor $\mathrm{X}$ variant (factor XMarseille). Eur J Biochem 234: 140-147.

77. Triplett DA (2000) Use of the dilute Russell viper venom time (dRVVT): its importance and pitfalls. J Autoimmun 15: 173-178.

78. Marsh NA (2001) Diagnostic uses of snake venom. Haemostasis 31: 211-217.

79. Nolan C, Hall LS, Barlow GH (1976) Ancrod, the coagulating enzyme from Malayan pit viper (Agkistrodon rhodostoma) venom. Methods Enzymol 45: 205-213.

80. Dempfle CE, Alesci S, Kucher K, Müller-Peltzer H, Rübsamen K, et al. (2001) Plasminogen activation without changes in tPA and PAI-1 in response to subcutaneous administration of ancrod. Thromb Res 104: 433-438.

81. Qin J, Xu Z, Shi D, Chen D, Dai J, et al. (2013) Deep vein thrombosis after total hip arthroplasty and total knee arthroplasty in patients with previous ischemic stroke. Int J Low Extrem Wounds 12: 316-319.

82. Serrano SM (2013) The long road of research on snake venom serine proteinases. Toxicon 62: 19-26.

83. Sherman DG, Atkinson RP, Chippendale T, Levin KA, $\mathrm{Ng} \mathrm{K}$, et al. (2000) Intravenous ancrod for treatment of acute ischemic stroke: the STAT study: a randomized controlled trial. Stroke Treatment with Ancrod Trial. JAMA 283 2395-2403.

84. Levy DE, del Zoppo GJ, Demaerschalk BM, Demchuk AM, Diener HC (2009) Ancrod in acute ischemic stroke: results of 500 subjects beginning treatment within 6 hours of stroke onset in the ancrod stroke program. Stroke 40: 3796-803

85. You KE, Koo MA, Lee DH, Kwon BJ, Lee MH, et al. (2014) The effective control of a bleeding injury using a medical adhesive containing batroxobin. Biomed Mater 9: 025002

86. Vu TT, Stafford AR, Leslie BA, Kim PY, Fredenburgh JC, et al. (2013) Batroxobin binds fibrin with higher affinity and promotes clot expansion to a greater extent than thrombin. J Biol Chem 288: 16862-16871.

87. Schonauer C, Tessitore E, Barbagallo G, Albanese V, Moraci A (2004) The use of local agents: bone wax, gelatin, collagen, oxidized cellulose. Eur Spine J 13 Suppl 1: S89-96.

88. Ofosu FA, Freedman J, Semple JW (2008) Plasma-derived biological medicines 
Citation: Chudzinski-Tavassi AM, Carrijo-Carvalho LC, Alvarez-Flores MP, Andrade SA (2014) Exogenous Procoagulant Factors as Therapeutic and Biotechnological Tools. J Blood Disorders Transf 5: 209. doi: 10.4172/2155-9864.1000209

Page 10 of 10

used to promote haemostasis. Thromb Haemost 99: 851-862.

89. Fang J, Gu L, Zhu N, Tang H, Alvarado CS, et al. (2008) Tissue factor/FVIla activates $\mathrm{Bcl}-2$ and prevents doxorubicin-induced apoptosis in neuroblastoma cells. BMC Cancer 8: 69 .

90. Joseph JS, Thirumangalathu S, Tsang F, Wong FW, Kini RM (2003) Trocarin, a blood coagulation factor $\mathrm{Xa}$ homologue from snake venom, causes inflammation and mitogenesis. Toxicon 42: 769-776.

91. Schattner M, Fritzen M, Ventura Jde S, de Albuquerque Modesto JC, Pozner RG, et al. (2005) The snake venom metalloproteases berythractivase and jararhagin activate endothelial cells. Biol Chem 386: 369-374.

92. Pereira AL, Fritzen M, Faria F, Motta G, Chudzinski-Tavassi AM (2006) Releasing or expression modulating mediator involved in hemostasis by Berythractivase and Jararhagin (SVMPs). Toxicon 47: 788-796

93. Cooke JP (2003) NO and angiogenesis. Atheroscler Suppl 4: 53-60.

94. Welling TH, Huber TS, Messina LM, Stanley JC (1996) Tissue plasminogen activator increases canine endothelial cell proliferation rate through a plasminindependent, receptor-mediated mechanism. J Surg Res. 66: 36-42.

95. Pinto AF, Dragulev B, Guimarães JA, Fox JW (2008) Novel perspectives on the pathogenesis of Lonomia obliqua caterpillar envenomation based on assessment of host response by gene expression analysis. Toxicon 51: 11191128.

96. Soendergaard C, Kvist PH, Seidelin JB, Nielsen OH (2013) Tissueregenerating functions of coagulation factor XIII. J Thromb Haemost 11: 806816.

97. Shimomura T, Kondo J, Ochiai M, Naka D, Miyazawa K, et al. (1993) Activation of the zymogen of hepatocyte growth factor activator by thrombin. $\mathrm{J}$ Biol Chem. 268: 22927-32.

98. Mars WM, Zarnegar R, Michalopoulos GK (1993) Activation of hepatocyte growth factor by the plasminogen activators UPA and tPA. Am J Pathol 143: 949-958.

99. Boccaccio C (2011) Hepatocyte Growth Factor: a marker and a player in disseminated intravascular coagulation. Thromb Res 127: 67-69.

100. Ohnishi T, Kakimoto K, Bandow K, Lowenstein CJ, Daikuhara Y, et al. (2006) Mature hepatocyte growth factor/scatter factor on the surface of human granulocytes is released by a mechanism involving activated factor Xa. J Immunol. 176: 6945-6953.

101. Delehedde M, Sergeant N, Lyon M, Rudland PS, Fernig DG (2001) Hepatocyte growth factor/scatter factor stimulates migration of rat mammary fibroblasts through both mitogen-activated protein kinase and phosphatidylinosito 3-kinase/Akt pathways. Eur. J. Biochem. 268: 4423-4429.

102. Imagawa S, Fujii S, Dong J, Furumoto T, Kaneko T, et al. (2006) Hepatocyte growth factor regulates $\mathrm{E}$ box-dependent plasminogen activator inhibitor type 1 gene expression in HepG2 liver cells. Arterioscler Thromb Vasc Biol 26 2407-2413.

103.Zeng Q, McCauley LK, Wang CY (2002) Hepatocyte growth factor inhibits anoikis by induction of activator protein 1-dependent cyclooxygenase-2. Implication in head and neck squamous cell carcinoma progression. J Bio Chem 277: 50137-50142.

104. You WK, Choi WS, Koh YS, Shin HC, Jang Y, et al. (2004) Functional characterization of recombinant batroxobin, a snake venom thrombin-like enzyme, expressed from Pichia pastoris. FEBS Lett 571: 67-73.

105. Yu X, Li Z, Xia X, Fang H, Zhou C, et al. (2007) Expression and purification of ancrod, an anticoagulant drug, in Pichia pastoris. Protein Expr Purif 55: 257-261.

106. Cereghino JL, Cregg JM (2000) Heterologous protein expression in the methylotrophic yeast Pichia pastoris. FEMS Microbiol Rev 24: 45-66.

107.Perchuc A, Wilmer M (2011) Diagnostic Use of Snake Venom Components in the Coagulation Laboratory, in Toxins and Hemostasis, In: Kini RM (Edr.) Springer Netherlands. pp: 747-766.

108. Thomson NC, Hutcheon AW, Dagg JH (1976) Acquired resistance to prolonged treatment with intravenous "Arvin" (ancrod). Br J Clin Pract 30: 232-233.

109. Chowdhury SM, Hubbell JA (1996) Adhesion prevention with ancrod released via a tissue-adherent hydrogel. J Surg Res 61: 58-64.

110. Hennerici MG, Kay R, Bogousslavsky J, Lenzi GL, Verstraete M, et al. (2006) Intravenous ancrod for acute ischaemic stroke in the European Stroke Treatment with Ancrod Trial: a randomised controlled trial. Lancet 368: 1871 1878.

111. Levy DE, del Zoppo GJ, Demaerschalk BM, Demchuk AM, Diener HC, et al (2009) Ancrod in acute ischemic stroke: results of 500 subjects beginning treatment within 6 hours of stroke onset in the ancrod stroke program. Stroke 40: 3796-3803.

112. Liu S, Marder VJ, Levy DE, Wang SJ, Yang F, et al. (2011) Ancrod and fibrin formation: perspectives on mechanisms of action. Stroke 42: 3277-3280.

113. Lei Zhang, Shi Hong Lu, Li Li, Tao YG, Yong Ling Wan, et al. (2011) Batroxobin mobilizes circulating endothelial progenitor cells in patients with deep vein thrombosis. Clin Appl Thromb Hemost 17: 75-79.

114. Yu X, Li Z, Xia X, Fang H, Zhou C, et al. (2007) Expression and purification of ancrod, an anticoagulant drug, in Pichia pastoris. Protein Expr Purif 55 257-261.

115. Burkhart W, Smith GF, Su JL, Parikh I, LeVine H 3rd (1992) Amino acid sequence determination of ancrod, the thrombin-like alpha-fibrinogenase from the venom of Akistrodon rhodostoma. FEBS Lett 297: 297-301.

116. You WK, Choi WS, Koh YS, Shin HC, Jang Y, et al. (2004) Functional characterization of recombinant batroxobin, a snake venom thrombin-like enzyme, expressed from Pichia pastoris. FEBS Lett 571: 67-73.

117. Cereghino JL, Cregg JM (2000) Heterologous protein expression in the methylotrophic yeast Pichia pastoris. FEMS Microbiol Rev 24: 45-66.

118. Filippovich I, Sorokina N, St Pierre L, Flight S, de Jersey J, et al. (2005) Cloning and functional expression of venom prothrombin activator protease from Pseudonaja textilis with whole blood procoagulant activity. $\mathrm{Br} \mathrm{J}$ Haematol 131: $237-246$

119. Minh Le TN, Reza MA, Swarup S, Kini RM (2005) Gene duplication of coagulation factor $\mathrm{V}$ and origin of venom prothrombin activator in Pseudonaja textilis snake. Thromb Haemost 93: 420-429.
This article was originally published in a special issue, Coagulation Disorders: Heparin Induced Thrombocytopenia handled by Editor(s). Dr. Domenico Calcaterra, University of lowa, USA

Citation: Chudzinski-Tavassi AM, Carrijo-Carvalho LC, Alvarez-Flores MP Andrade SA (2014) Exogenous Procoagulant Factors as Therapeutic and Biotechnological Tools. J Blood Disorders Transf 5: 209. doi: 10.4172/21559864.1000209 